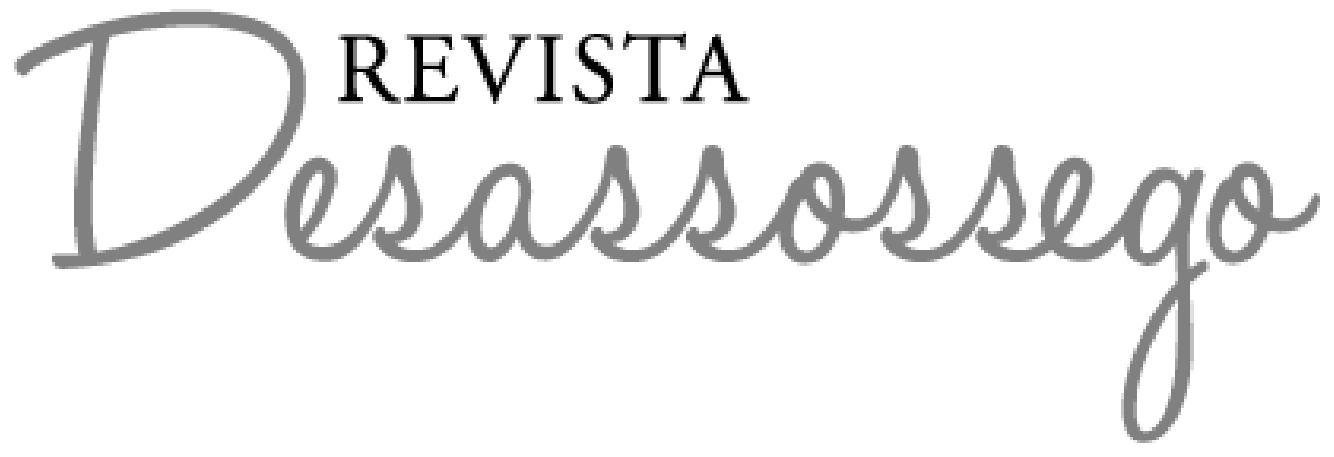

A Literatura Portuguesa e a História

Bruno Anselmi Matangrano

Leonardo de Barros Sasaki

(editores-responsáveis) 


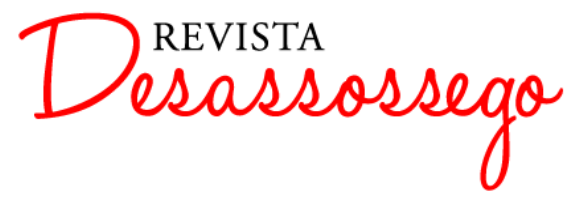

DESASSOSSEGO 20 | DEZ/2018 | ISSN 2175-3180

DOI: http://dx.doi.org/10.11606/issn.2175-3180.v10i20p2-4

\section{A Literatura Portuguesa e a História}

Em sua Poética, Aristóteles se ocupou de comprar história e literatura, pondo-as em perspectiva por notar a relação estabelecida por uma ciência capaz de narrar, de um lado, o que de fato aconteceu e, de outro lado, uma ciência capaz de especular sobre tudo aquilo que poderia ter acontecido. $\mathrm{Na}$ literatura portuguesa, em particular, esse diálogo foi bastante profícuo: pensamos, por exemplo, no mais canônico de seus textos, Os Lusíadas, no qual Camões mistura o histórico ao mítico costurados por sua linguagem poética. Já Alexandre Herculano e Camilo Castelo Branco, no século XIX, dedicam-se a recontar acontecimentos, numa ambientação que recupera aspectos de outrora, inserindo-se no nascente gênero do "romance histórico", caminho que seria seguido por outras figuras essenciais para o contexto português ao longo dos séculos XX e XXI, como o laureado José Saramago e diversos nomes de relevo, entre eles Mário de Carvalho, Miguel Real e Pedro Almeida Vieira.

Tendo em vista esse terreno fértil de possibilidades analíticas e interpretativas, para seu vigésimo número, a Revista Desassossego convidou os pesquisadores interessados na literatura e nas artes portuguesas a repensarem as relações entre essas duas grandes disciplinas afins, para se discutir seja romance histórico - enquanto gênero capaz de revisitar a história, mas não se restringindo a ela -, seja o "fato histórico" na literatura, seja também o elemento literário em relatos históricos e historiográficos, e, por que não, seja, ainda, a própria noção de história da literatura. O resultado foi um dossiê rico e diverso que se desdobrou em dois números: em sua primeira parte, reunimos os oito artigos agora apresentados neste vigésimo número, enquanto os demais trabalhos serão compilados no número 21 , a ser publicado em junho de 2019.

Como não poderia deixar de ser, nosso dossiê se abre com um artigo sobre Luís de Camões intitulado "Retórica e memória em algumas estrofes d'Os Lusíadas", assinado por Lourival da Silva Burlamaqui Neto. Nesse trabalho, o autor demonstra através de versos da épica camoniana como o poema se valeu de textos de época em um movimento de resgate da memória de seu povo para construir uma epopeia que o louva, a partir de rigorosos recursos retóricos cujas técnicas o poeta dominava.

O texto seguinte, "Poesia e exílio: passos do decadentismo português", de Patrícia Helena Baialuna de Andrade, avança alguns séculos para tratar do fin de siècle oitocentista, mantendo-se, contudo, no âmbito da lírica portuguesa. Em uma conjuntura de grande efervescência cultural, marcada por movimentos e estéticas distintos, Andrade demonstra 


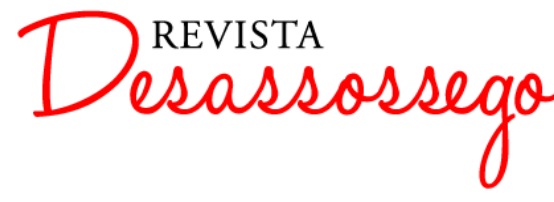

sob um viés historiografista como os poetas de então trabalharam os temas do exílio e do sentimento de não pertencimento, de um ponto de vista tanto espacial quanto temporal.

Já em "Poesia e história: considerações sobre Fernando Pessoa e Manuel Alegre", Marcelo Ferraz de Paula chega à Geração de Orpheu, analisando um poema do heterônimo Ricardo Reis, em perspectiva comparada com outro do poeta contemporâneo Manuel Alegre. $\mathrm{O}$ autor identifica em ambos um sentimento de alheamento em relação à catástrofe histórica, seja a guerra, no caso do primeiro, seja o terremoto lisboeta, no caso do segundo, de modo a incitar possíveis formas de diálogo entre a poesia e o fato histórico.

Os demais textos de nosso dossiê se debruçam sobre a prosa moderna e contemporânea, começando com dois artigos dedicados ao escritor José Saramago. No primeiro, intitulado "Ricardo Reis: um homem e um ano", Demétrio Alves Paz propõe uma leitura intertextual na qual se pretende estabelecer articulações entre ficção e história no romance, recuperando figuras literárias e reais nele mencionadas. Essa também é a perspectiva adotada por Francisca Carolina Lima da Silva em "A reescrita dos mitos bíblicos em José Saramago: a re-historização do sagrado a partir da ficção”. Em seu trabalho, a pesquisadora analisa o processo de "desconstrução" dos "textos com os quais as obras dialogam”. Para demonstrar sua hipótese, volta-se, então, ao livro O Evangelho de Jesus Cristo.

Em seguida, Denise Rocha em seu estudo "Vítimas fatais do salazarismo: realidade e ficção em Balada da praia dos cães: dissertação sobre um crime (1982), de José Cardoso Pires" discute a construção polifônica da narrativa cardosiana pelo prisma da literatura policial, de modo a demonstrar como essa forma discursiva revela a atmosfera de medo e violência do Portugal de Salazar, misturando acontecimentos históricos embasados em diversos documentos à elaboração literária.

Por sua vez, em "Subversões perversas da escrita: espaço e corpo, testemunhos em Gonçalo M. Tavares", avançando rumo ao ultracontemporâneo, Fabio Fadul Moura nos apresenta a releitura literária de um acontecimento histórico de grande gravidade, o Holocausto, que Gonçalo M. Tavares empreende em Uma menina está perdida no seu século à procura do pai, publicado em 2015.

O dossiê se encerra com a análise de um texto dramático, no artigo " $A$ confissão, de Bernardo Santareno: da diferença como locus de luta política", elaborado a quatro mãos por Solange S. Santana e Márcio Ricardo Coelho Muniz. Nesse estudo, outra vez é evocada a ditadura salazariana, mais especificamente seu momento final com a Revolução dos Cravos. A publicação do texto de Santareno ocorre poucos anos antes desse momento histórico. 
Nele, o testemunho "denuncia a opressão e a discriminação" presentes naquela sociedade em conflito.

Por fim, trazemos um poema de Isadora Machado intitulado "Dois Cantos de maldição e memória" e uma extensa e cuidadosa entrevista intitulada "Eduardo Lourenço: amigo dos poetas", concedida aos professores Paola Poma e Fernando Ribeiro, na qual o célebre crítico e filósofo português conta um pouco de sua relação de admiração, interesse e afeto pela poesia portuguesa, verdadeiro testemunho de valor histórico.

Diante de tão instigantes temas e discussões, desejamos a todos excelente leitura!

Os Editores,

Bruno Anselmi Matangrano e Leonardo de Barros Sasaki. 